\title{
Awaria budynku zabytkowego w wyniku realizacji prac budowlanych w sąsiedztwie
}

\section{Tomasz Błaszczyński}

\begin{abstract}
Instytut Konstrukcji Budowlanych, Wydział Budownictwa i Inżynierii Środowiska, Politechnika Poznańska, e-mail: tomasz.blaszczynski@put.poznan.pl
\end{abstract}

Streszczenie: W związku z projektowaną budową wielofunkcyjnego budynku biurowo-usługowego w Poznaniu, a także w związku z przewidywaną modernizacją technicznej infrastruktury podziemnej, powinna zachodzić potrzeba inwentaryzacji i oceny stanu technicznego istniejących obiektów sąsiednich. Także zgodnie z wymogami sformułowanymi w decyzji o warunkach zabudowy oraz zgodnie z uwagami zawartymi we wcześniejszych ekspertyzach, powinno się wykonać te prace. Inwentaryzacja i ocena stanu technicznego istniejących obiektów sąsiednich powinna być wykonana pod kątem wpływu budowy na nie i przeciwdziałania ewentualnym skutkom związanym z realizacją projektowanych robót w sąsiedztwie. Niestety inwestor takich prac nie podjął, a realizowane prace doprowadziły do stanu awaryjnego w analizowanym budynku zabytkowym.

Słowa kluczowe: budynek zabytkowy, awaria, stan awaryjny, prace budowlane.

\section{Wprowadzenie}

Analizowany budynek zabytkowy został wzniesiony prawdopodobnie w drugiej połowie XIXw., w technologii tradycyjnej - murowanej. Od strony wschodniej, graniczy on bezpośrednio z działką nr 31 (Rys. 1), na której właśnie realizowany jest nowy budynek wielofunkcyjny. Od strony północnej niemal cały budynek przylega do ścian szczytowych dwóch oficyn należących do sąsiedniego budynku mieszkalnego.

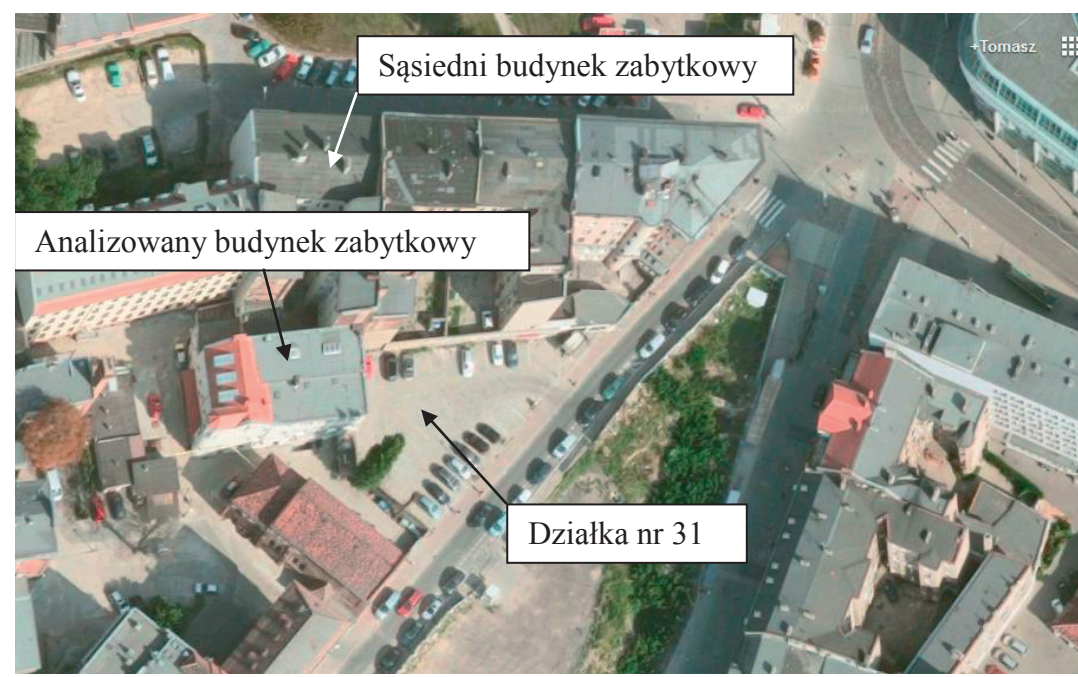

Rys. 1. Widok na analizowany teren 
Obiekt jest w większości podpiwniczony (z wyłączeniem fragmentu przylegającego do wschodniej ściany szczytowej, czyli działki nr 31 - Rys. 1) i w dawnych czasach był prawdopodobnie poddany rozbudowie. W bryle całego budynku wyróżnić można zachodnią część starszą 4-ro kondygnacjową (najprawdopodobniej pierwotną z drugiej połowy XIXw.) i nowszą część zlokalizowaną przy działce nr 31, trzykondygnacjową, która najprawdopodobniej była wynikiem przebudowy lub dobudowy do pierwotnego budynku. Ze względu na zastosowane technologie i rozwiązania konstrukcyjne, należy przypuszczać, że tej przebudowy lub dobudowy, dokonano w drugiej połowie lat dwudziestych XXw. Obie te części połączono w jedną całość tworząc spójny wewnętrzny układ funkcjonalny, wyposażony w dwie oddzielne klatki schodowe (starszą - drewnianą i nowszą - żelbetową). Część starsza budynku jest przekryta dachem dwuspadowym natomiast część niższa późniejsza przekryta jest dachem płaskim typu pulpitowego (Rys. 2).

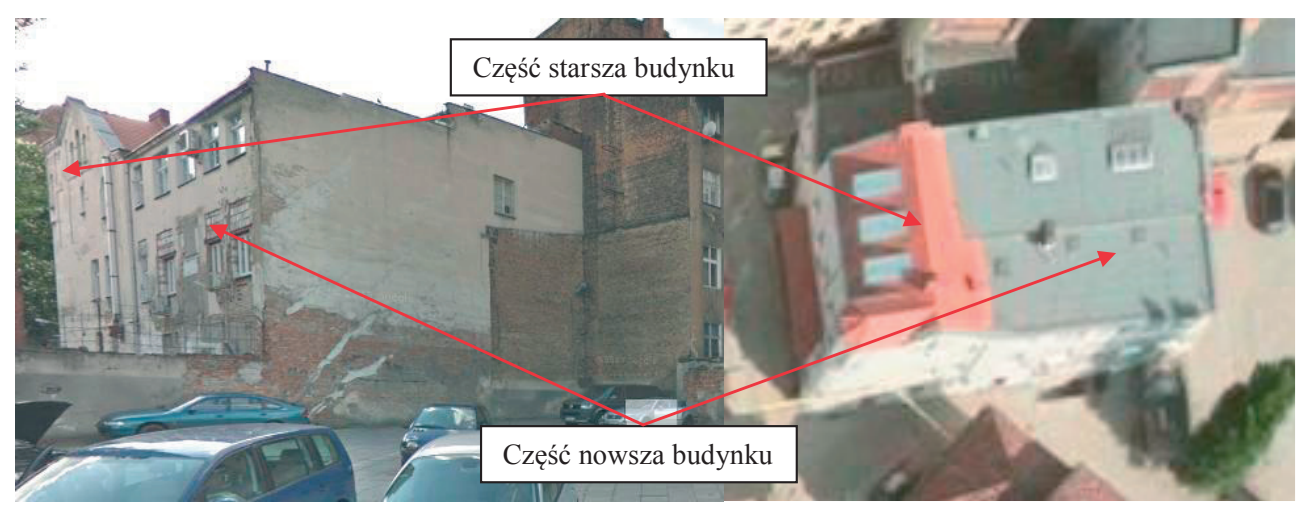

Rys. 2. Analizowany budynek zabytkowy

Konstrukcję budynku stanowią:

a) w przypadku części starszej:

- murowane ściany zewnętrzne i wewnętrzne, o zróżnicowanej grubości i wewnętrzny układ słupowo-belkowy (dwa słupy + podciąg poprzeczny i podłużne żebra),

- stropy międzykondygnacjowe o poprzecznym układzie nad piwnicami i podłużnym na wyższych kondygnacjach: są to stropy w postaci sklepień odcinkowych na belkach stalowych (od piwnicy - I160 do I piętra - I140), a nad II piętrem jest strop drewniany belkowy,

- zabiegowe schody drewniane w części wieżowej i wewnętrzne drewniane do piwnicy,

- drewniana dachowa konstrukcja płatwiowo-kleszczowa z dwoma ściankami stolcowymi.

b) w przypadku części nowszej:

- murowane ściany zewnętrzne i wewnętrzne o układzie podłużnym i wewnętrzny układ szkieletowy (filar lub słup podpierające podłużny podciąg),

- masywne ceramiczno-betonowe stropy międzykondygnacjowe typu Ackermana lub na belkach stalowych typu Kleina nad piwnicą, wyżej (nad parterem) - typu Ackermana i strop żelbetowy płytowy na żebrach poprzecznych nad I piętrem,

- drewniany stropodach belkowy, jednospadowy z uskokiem w środkowej części budynku,

- żelbetowa klatka schodowa, dwubiegowa. 
W chwili dokonywania przeglądów, w budynku znajdowała się apteka, magazyny i archiwum, pomieszczenia biurowe oraz świetlica i szkoła przyszpitalna. W związku z charakterem użytkowania większość pomieszczeń była wyremontowana, a elementy konstrukcyjne zasłonięte i niedostępne. Fundamenty w analizowanym obiekcie wykonano, jako kamienno-ceramiczne (Rys. 3).

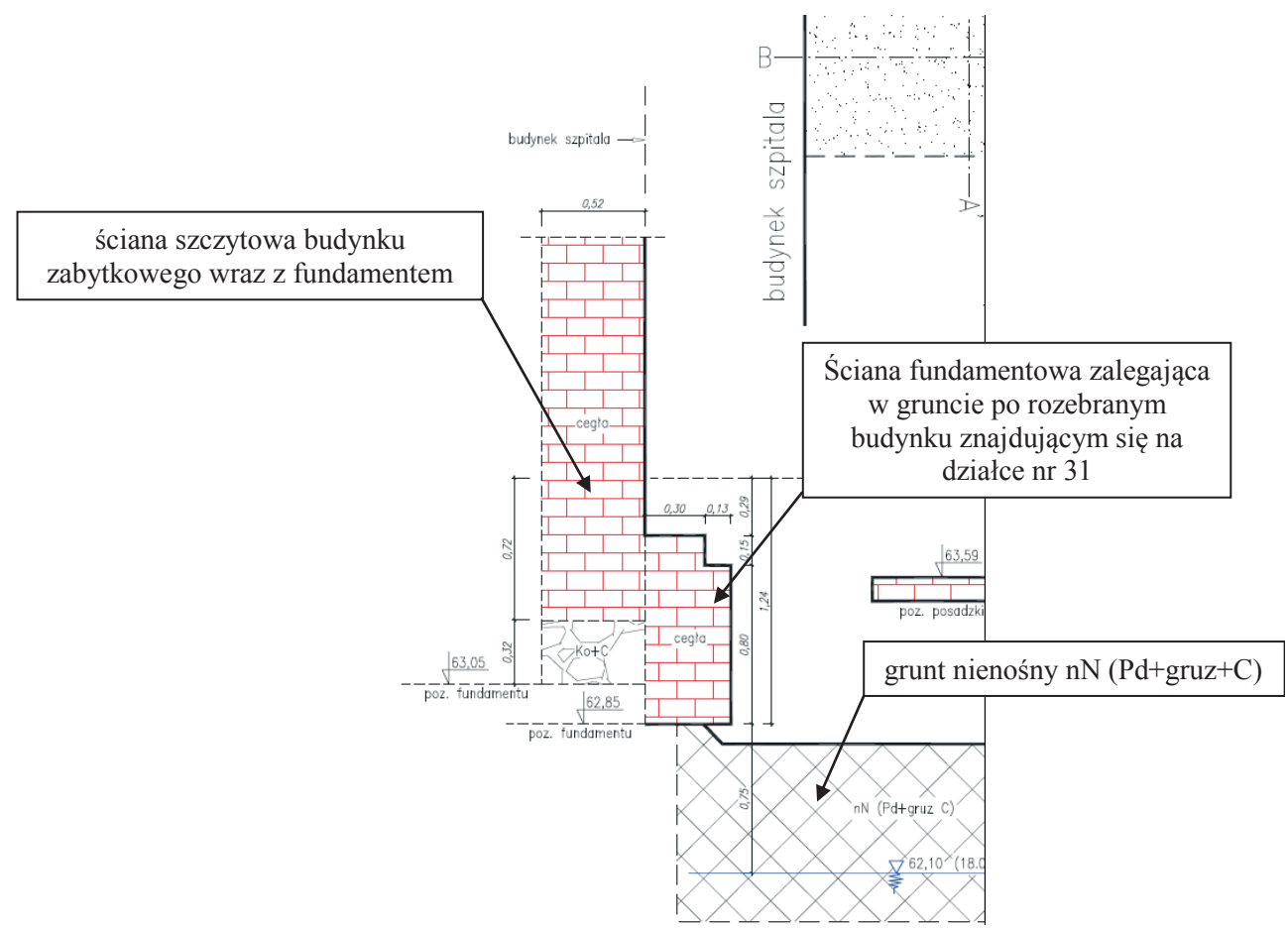

Rys. 3. Odkrywka fundamentu w ścianie szczytowej analizowanego budynku zabytkowego $[3,4]$

Należy podkreślić, że zgodnie z ekspertyzą wykonaną przez inwestora zabudowującego działkę nr 31 (w roku 2006) część nowsza jest w znacznie gorszym stanie technicznym niż część starsza [1]. Niestety inwestor nowo realizowanego obiektu nie wykonał aktualnej ekspertyzy, czyli po 8 latach od poprzedniej. Natomiast kolejna ekspertyza została wykonana dopiero zaraz po awarii analizowanego budynku [2].

Na zabudowywanej działce nr 31 znajdował się kiedyś budynek mieszkalny, który został zniszczony przez działania wojenne, a następnie rozebrany do poziomu terenu. Stwierdzono to z przekazów archiwalnych i wykonanych odkrywek (Rys. 3). W takcie badań geologicznych [3, 4] wykonano odkrywkę przy ścianie szczytowej budynku zabytkowego, od strony nowej inwestycji (Rys. 4). W odkrywce widoczne jest, iź ściana szczytowa budynku szpitalnego oparta jest na podwalinie o wysokości $0,32 \mathrm{~m}$, wykonanej z luźno ułożonych kamieni i cegieł, która posadowiona jest na gruntach nasypowych. W odkrywce odsłonięto również fragmenty murów ceglanych wyburzonego budynku. Usytuowane są one równolegle do ścian istniejącego budynku, ale bez połączenia (przemurowania) i posadowione są na głębokości $70 \mathrm{~cm}$ poniżej spodu podwaliny ściany szczytowej budynku zabytkowego W odkrywce zaobserwowano wodę gruntową z sączeń w nasypach na stropie glin. 


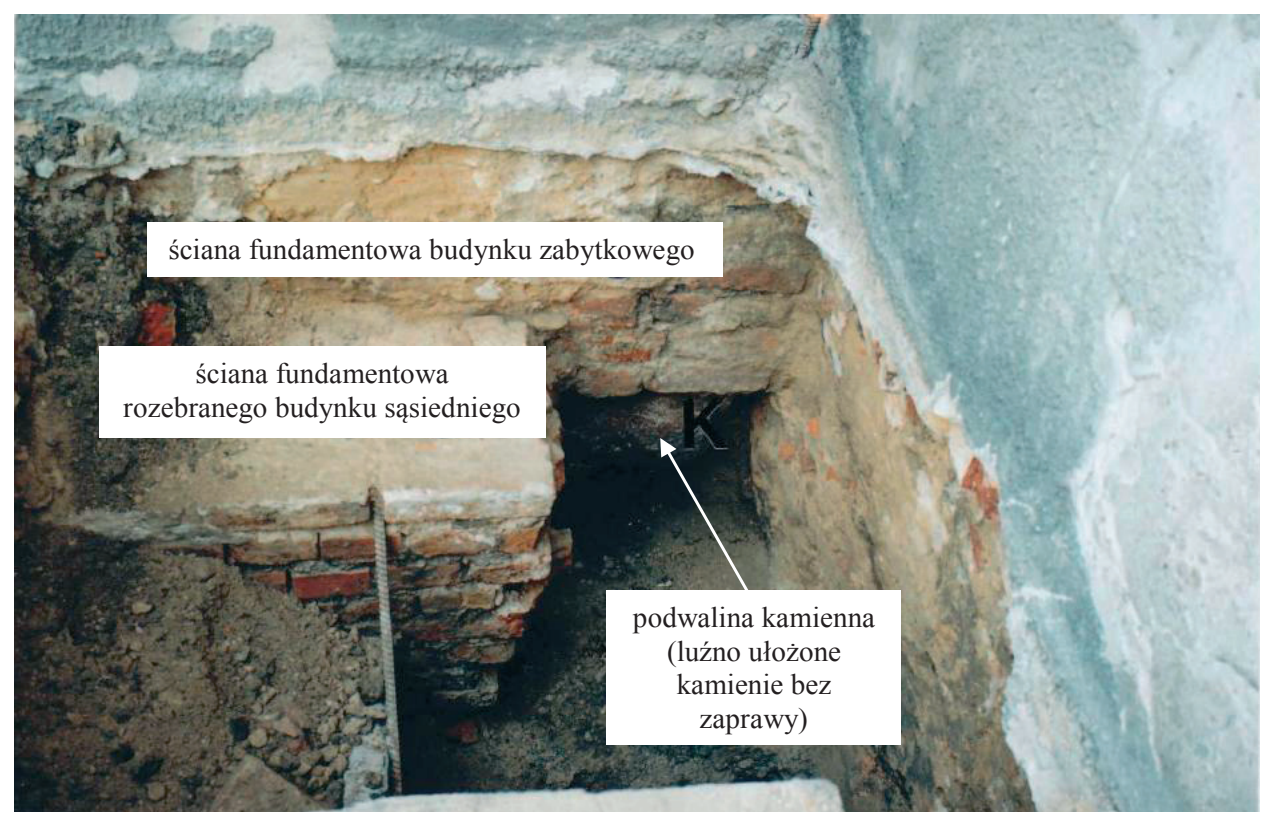

Rys. 4. Widok na fundament budynku zabytkowego i pozostałą w gruncie ścianę rozebranego budynku

W najgorszym stanie technicznym było naroże ściany szczytowej, która uległa awarii. W narożu łączącym ścianę szczytową ze ścianą podłużną stwierdzono pęknięcie z rozwarstwieniem i odspojenie się części ściany szczytowej (na wysokości parteru) wraz z jej wybrzuszeniem, przy granicy z nieruchomością, na której prowadzona jest budowa (Rys. 5). W najszerszym miejscu powstała szczelina o szerokości ok. $9 \mathrm{~cm}$.

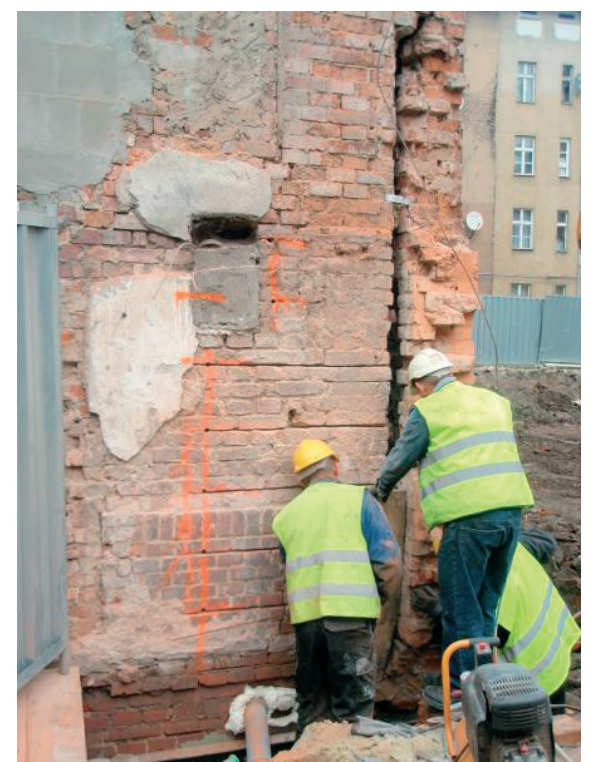

Rys. 5. Pęknięcie rozwarstwiające ścianę szczytową od reszty budynku zabytkowego 
Awaria analizowanego budynku zabytkowego spowodowała znaczne zarysowania, które stwierdzono również na wszystkich kondygnacjach w strefie ściany szczytowej (Rys. 6,7). Praktycznie dotyczyło to całej ściany szczytowej oraz związanych z nią fragmentów niektórych elementów konstrukcyjnych, jak dochodzące do niej ściany, filary, stropy czy podciągi.
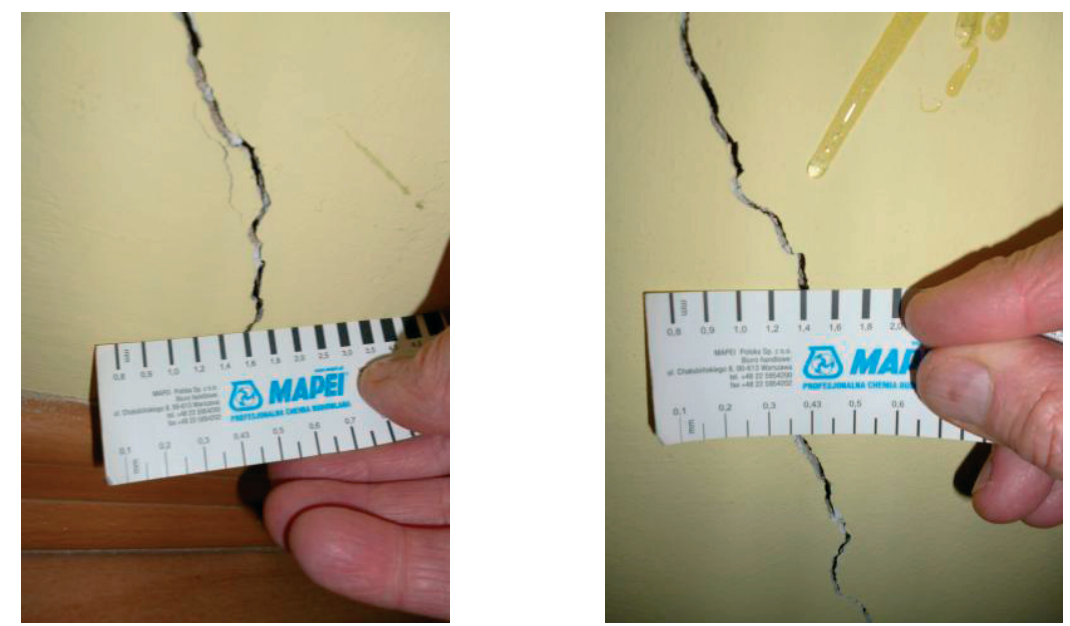

Rys. 6, 7. Zarysowania na ścianie szczytowej w pomieszczeniu świetlicy na II p. budynku zabytkowego

\section{Nowo realizowany budynek w sąsiedztwie}

Nowo realizowany obiekt biurowo-usługowy posiadać miał 5 kondygnacji nadziemnych i nie miał być podpiwniczony. Zaprojektowany został jako przyległy do ściany szczytowej analizowanego budynku zabytkowego. Nowy budynek zaprojektowano w formie zwartej jednobryłowej, o wysokości nieodbiegającej od wysokości budynków sąsiednich (Rys. 8).

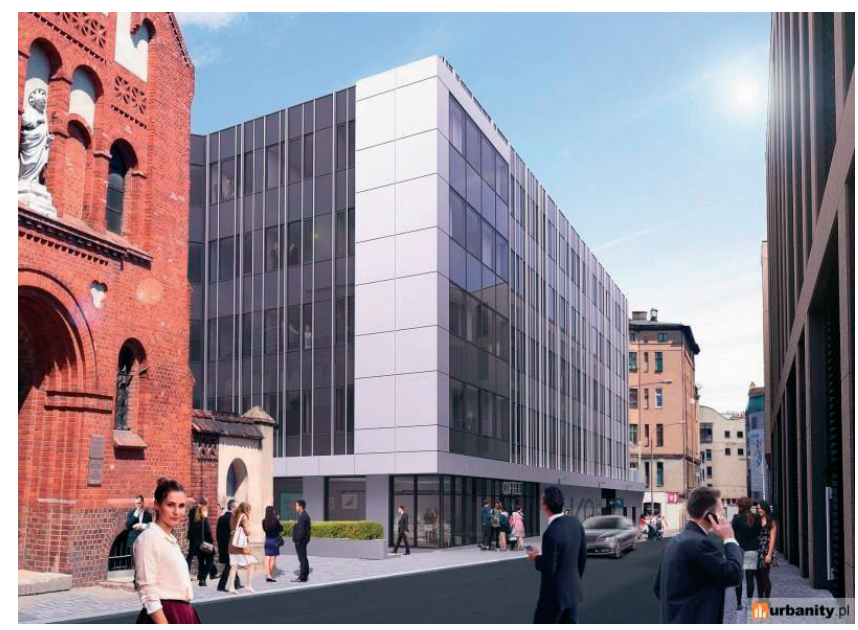

Rys. 8. Wizualizacja realizowanego na działce sąsiedniej budynku biurowo-usługowego 
Konstrukcję główną budynku stanowią żelbetowe ściany monolityczne o gr. 0,25 m oraz układ szkieletowy słupowo-ryglowy i monolityczne stropy grzybkowe z wykorzystaniem systemu Filigran o grubości 0,25 m. Komunikację stanowić będą również żelbetowe schody monolityczne. Ściany projektowanego budynku przy istniejących budynkach sąsiednich planuje się posadowić na oczepach, pod które zostaną wykonane pale CFA o długości ok. $7 \mathrm{~m}$, w rozstawie co 2,5 m. Spód oczepu kolumn CFA, który ma być zlokalizowany wzdłuż analizowanego budynku zabytkowego, został zaprojektowany na poziomie 61,78 i 61,43 m n.p.m., czyli od 1,27 do 1,39 m poniżej istniejącego fundamentu tego budynku (Rys. 9). Po mimo to projekt nie przewidywał żadnych zabezpieczeń budynków sąsiednich. Na niezbędne podstawowe zabezpieczenia w stosunku do istniejącego budynku zabytkowego, wskazywała już ekspertyza z 2006 [1].

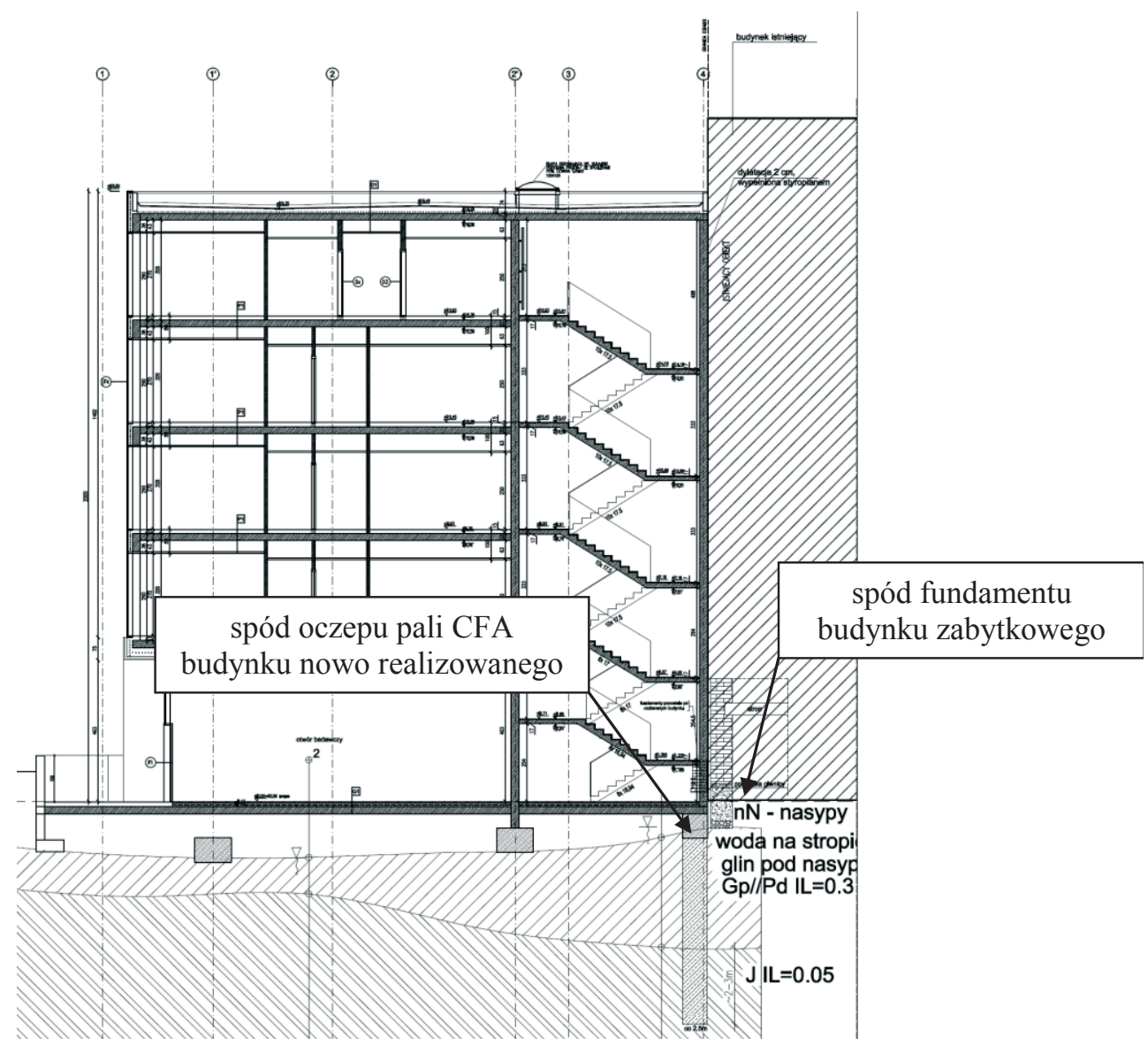

Rys. 9. Przekrój nowo realizowanego budynku w sąsiedztwie budynku zabytkowego

W stosunku do otaczających budynków zabytkowych nie przewidywano również żadnego systemu monitorującego, ani podstawowego, czyli geodezyjnego, ani bardziej zaawansowanego wielostopniowego $[5,6]$.

W ramach prowadzonych prac na działce nr 31 przystąpiono do usuwania starych murów znajdujących się w gruncie, bez projektu rozbiórki i bez pozwolenia na nią. Nie zawiadomiono również władz konserwatorskich i archeologa, w związku z prowadzeniem prac 
w strefie ochrony konserwatorskiej. W ramach tych prac, bez żadnych zabezpieczeń, wykonano głęboki wykop wzdłuż ściany szczytowej budynku zabytkowego. Wykop ten miał głębokość ok. 1,5 do 2,0 m i szerokość ok. 4,0 m, czyli musiał być głębszy od poziomu posadowienia fundamentu ściany szczytowej budynku zabytkowego. Wynika to jednoznacznie z analizy Rys. 3, 4 i 9. Następstwem tych prac była awaria w strefie ściany szczytowej budynku zabytkowego w wyniku, której przerwano budowę i podparto awaryjnie wybrzuszoną i pękniętą ścianę szczytową.

\section{Analiza wpływu realizacji prac w sąsiedztwie na budynek zabytkowy}

Analizując i oceniając wpływ realizowanej inwestycji na analizowany budynek zabytkowy należy rozpocząć od okresu z przed realizacji inwestycji na działce nr 31 . Nagannym jest nie wykonanie aktualnej ekspertyzy (dot. stanu technicznego budynku zabytkowego) przez inwestora noworealizowanej inwestycji, tym bardziej, że jest to jeden z elementów zabezpieczających interes osób trzecich. Naganne jest również to, że inwestor miał tego świadomość, gdyż przed budową zbierał oferty od ważniejszych ekspertów w mieście na wykonanie ekspertyz budynków będących w otoczeniu działki nr 31. Do wyboru eksperta i wykonania aktualnej ekspertyzy nie doszło, prawdopodobnie $\mathrm{w}$ związku z brakiem takiego wymogu ze strony Urzędu Miasta, przy wydawaniu pozwolenia na budowę. W związku z tym podjęto decyzję o oszczędnościach na aktualnych ekspertyzach budynków sąsiednich. Dodatkowo kierownik budowy wraz z inwestorem, z premedytacją, podjęli decyzję o kolejnych oszczędnościach i niezabezpieczaniu budynku zabytkowego, przed wpływami realizowanej budowy. Tym samym narażając ten budynek na przyszłą awarię. Stwierdzenie zawarte w [1], że stan techniczny ściany szczytowej w budynku zabytkowym jest zły, nie upoważniał kierownika budowy (w porozumieniu $\mathrm{z}$ inwestorem) do nic nie robienia. Natomiast podstawowym ich obowiązkiem było odpowiednie zabezpieczenie budynku zabytkowego. Należy podkreślić, że budynek ten znajdując się w stosunkowo dobrym stanie technicznym przed rozpoczęciem budowy na działce sąsiedniej, nie uległby awarii nawet przez kolejne kilkadziesiąt lat.

\section{Podsumowanie}

Należy wyraźnie podkreślić, że przez to, iż żadnego z zaleceń zawartych w [1] kierownik budowy nie zrealizował doszło do awarii, a szczególnie naganne było dopuszczenie się odsłonięcia fundamentów ściany szczytowej budynku zabytkowego i dodatkowego jej podkopania. Cały ten ciąg zaniechan doprowadził do aktualnego stanu awaryjnego strefy ściany szczytowej analizowanego budynku zabytkowego. Praktycznie tylko szczęście uchroniło obiekt przed większą katastrofą. Należy podkreślić, że gdyby cały obiekt był wykonstruowany, tak jak jego część starsza, to nie tylko mówilibyśmy o awarii, ale o katastrofie. Podkopanie fundamentu ściany szczytowej doprowadziłoby wtedy do jej zawalenia i pociągnięcia za sobą części stropów, wraz z ludźmi, którzy by w tej części pracowali. Tylko to, że ta część budynku (od strony ściany szczytowej) została prawdopodobnie przebudowana w okresie późniejszym i w znacznie sztywniejszej konstrukcji (układ ramowy ze sztywnymi stropami Ackermana, Kleina i żelbetowym stropem płytowym na żebrach), doszło do zawieszenia się i tylko zarysowania analizowanej ściany szczytowej, na tym sztywnym podłużnym układzie konstrukcyjnym, a nie do jej zawalenia się do wykopu. 


\title{
Literatura
}

1. Marcinkowski K. Ekspertyza techniczna dot. stanu konstrukcji budynku „C” Szpitala Dziecięcego im. Bolesława Krysiewicza w Poznaniu przy ul. Krysiewicza 7/8 w związu z projektowana w sasiedztwie budowa budynku ustugowo-biurowo-handlowego z czterokondygnacyjna częścia podziemna. Poznań 2006.

2. Błaszczyński T. Ekspertyza w sprawie stanu technicznego budynku administracyjnego „,C” szpitala przy ul. Krysiewicza 7/8 w Poznaniu, znajdującego się na dz. Nr 32/2, ark. 40, obręb Poznań, przy granicy z nieruchomościa przy ul Krysiewicza 9 w Poznaniu. Poznań 2014.

3. Dokumentacja geologiczna dot. sposobu posadowienia budynków przylegających do działki nr 31 i 44 przy ul. Krysiewicza w Poznaniu, GEOPROJEKT-POZNAŃ 2005.

4. Dokumentacja geologiczno-inżynierska dla określenia warunków geologiczno - inżynierskich w podłożu projektowanego budynku usługowo-biurowo-handlowego u zbiegu ulic Półwiejskiej i Krysiewicza w Poznaniu, GEOPROJEKT-POZNAŃ 2005.

5. Błaszczyński T., Oleksiejuk H., Firlej E., Błaszczyński M. Wielostopniowy monitoring $i$ zabezpieczenie budynków pod ochroną konserwatorska przed awaria budowlana. XXV Konferencja Naukowo-Techniczna Awarie Budowlane, Szczecin-Międzyzdroje, 2011, 395-402.

6. Błaszczyński T., Oleksiejuk H., Firlej E., Błaszczyński M. Jak zapobiec awariom budynków zabytkowych w sąsiedztwie realizacji budynku gtębokiego?, Builder 8 (2011) 42-43.

\section{The failure of the listed building as result of the realization of construction work in the neighbourhood}

\author{
Tomasz Błaszczyński \\ Institute of Structural Engineering, Faculty of Civil and Environmental Engineering, \\ Poznan University of Technology,e-mail: tomasz.blaszczynski@put.poznan.pl
}

\begin{abstract}
In connection with new designed construction of retail-office building in Poznań, and also in connection with the foreseen modernization of the technical underground infrastructure, it should happened the necessity of inventory and the estimation of the technical state of existing neighbouring objects. Also formally with formulated in the decision land development and in accordance with the references contained in earlier expertises, these works should be execute. The inventory and the estimation of the technical state of existing neighbouring objects should be performed in the connection with the influence of new construction in the vicinity on these objects and with counteractions to possible results connected with the realization of designed works in the neighbourhood. Unfortunately the investor did not undertake such works, and realized works brought to the failure state in analysed listed building.
\end{abstract}

Keywords: listed building, failure, failure state, construction work. 